\title{
Transformasi televisi sebagai media belajar di tengah pandemi dalam kacamata rasional instrumental
}

\author{
Rohmatin Alfianistiawati, Pramana Herjati Putra Dionchi, Hasna Bararah M, Joan Hesti \\ Gita Purwasih* \\ Universitas Negeri Malang, Jl. Semarang No. 5 Malang, Jawa Timur, Indonesia \\ *Penulis korespondensi, Surel: joan.hesti.fis@um.ac.id
}

Paper received: 03-02-2021; revised: 15-02-2021; accepted: 28-02-2021

\begin{abstract}
During the Covid-19 pandemic, various areas of life experienced changes and adjustments, including in the field of education by conducting distance learning. As a form of adjustment for distance learning, the government and educators use television as a learning medium. The transformation of television as a learning medium is aimed at every level of education, one of which is at the high school level. This study aims to determine the form of television transformation in the perspective of the instrumental rational theory as well as the perspective of students on learning through television. This research was conducted using descriptive qualitative methods with data collection techniques through observation and interviews. The results obtained in the form of structured programs during learning through television as a form of instrumental rational action during distance learning as well as the perspective of students with this transformation.
\end{abstract}

Keywords: transformation; learning media; pandemic; instrumental rationale.

\begin{abstract}
Abstrak
Pada masa pandemi Covid-19 berbagai bidang dalam kehidupan mengalami perubahan serta penyesuaian, termasuk pada bidang pendidikan dengan mengadakan pembelajaran jarak jauh. Sebagai bentuk penyesuaian pembelajaran jarak jauh tersebut pihak pemerintah serta pendidik memanfaatkan televisi sebagai media belajar. Transformasi televisi sebagai media belajar ini ditujukan pada setiap jenjang pendidikan, salah satunya pada jenjang sekolah menengah. Penelitian ini bertujuan untuk mengetahui bentuk transformasi televisi dalam perspektif teori rasional instrumental tersebut serta perspektif peserta didik akan kegiatan belajar memelalui televisi. Penelitian ini dilakukan dengan menggunakan metode kualitatif deskriptif dengan teknik pengumpulan data melalui observasi serta wawancara. Hasil yang diperoleh berupa adanya program terstruktur selama pembelajaran melalui televisi sebagai bentuk tindakan rasional instrumental selama pembelajaran jarak jauh serta perspektif peserta didik dengan adanya transformasi tersebut.
\end{abstract}

Kata kunci: transformasi; media belajar; pandemi; rasional instrumental.

\section{Pendahuluan}

Beberapa waktu terakhir dunia diguncangkan dengan adanya wabah pandemi Covid-19. Wabah yang pertama kali muncul di Kota Wuhan China ini ditengarai sebagai salah satu penyebab kematian tertinggi. Penyebaranya yang sangat cepat dan luas menimbulkan keresahan di berbagai negara, termasuk Indonesia. Guna menekan angka penyebaran Covid19 pemerintah mengeluarkan kebijakan pembatasan sosial berkskala besar atau PSBB. Sehingga kemunculan wabah ini mampu mengubah berbagai aspek kehidupan. Salah satunya pada bidang pendidikan yang mengalami perubahan pada penerapan aktifitas pembelajaranya. Dalam bidang pendidikan kegiatan pembelajaran dituntut untuk tetap berlangsung ditengah kondisi pendemi dengan tetap menerapkan kebijakan PSBB. Berdasarkan hal ini Kementerian Pendidikan dan Kebudayaan mengeluarkan surat edaran No. 
4 Tahun 2020 tentang pelaksanaan kebijakan pendidikan dalam masa darurat pandemi Covid19.

Kebijakan tersebut berisi mengenai tata cara pelaksanaan kegiatan pembelajaran secara online atau dalam jaringan selama masa pandemi. Hal ini dilakukan agar aktifitas pembelajaran tetap berjalan ditengah kondisi pandemi dengan memanfaatkan teknologi yang ada. Melalui pembelajaran berbasis daring guna memenuhi kebutuhan pendidikan di masa pandemi terjadi berbagai macam transformasi sarana dan prasana pendidikan. Transformasi ini berupa pemanfaatan berbagai teknologi yang ada salah satunya yaitu media televisi. Televisi yang pada umumnya menyajikan berbagai hiburan bagi penontonya bertransformasi menjadi sarana pembelajaran bagi para pelajar.

Televisi merupakan salah satu media elektronik yang mampu mengirimkan gambar bergerak dan suara melalui kabel ataupun ruang yang berfungsi sebagai penyedia informasi dan hiburan. Televisi memiliki sistem penyiaran dengan mengubah cahaya serta suara kedalam suatu gelombang elektronik sehingga dapat dilihat dan didengar (Sudarsana et al., 2020). Pada sebuah televisi terdapat berbagai macam sirkuit elektronik dengan prinsip pemancaran dan penangkapan pemencarannya hampir sama dengan radion. Sehingga dalam hal ini televisi mampu menyebarkan informasi baik berupa gambar dan suara yang mampu dijangkau oleh semua penonton.

Berdasarkan hal tersebut pada masa pandemi ini televisi mengalami transformasi bukan hanya memiliki fungsi hiburan namun juga fungsi pendidikan. Fungsi pendidikan yang dimiliki oleh televisi di masa pandemi berupa sarana dalam menyiarkan materi pembelajaran bagi peserta didik mulai dari tingkat SD sampai SMA. Dalam hal ini televisi dinilai mampu menjadi media belajar yang cukup efektif dan efisien di masa pandemi. Televisi mampu menyediakan materi pembelajaran yang memadai yang sesuai dengan jenjang pendidikan peserta didik. Televisi pendidikan ini memberikan program video yang dirancang untuk menyampaikan materi bukan hanya sekedar menghibur.

Pemanfaatan televisi pendidikan ini juga dilakukan pada jenjang pendidikan SMA termasuk pada SMAN 1 Trenggalek. Pada saat pembelajaran di rumah pemerintah menyiapkan televisi pendidikan bagi para peserta didik. Hal ini dilakukan melalui penyiaran materi pada salah satu stasiun televisi yaitu TVRI guna memenuhi hak belajar peserta didik. Pihak sekolah kemudian memberikan himbauan kepada para peserta didiknya untuk mengikut program tersebut, termasuk SMAN 1 Trenggalek. peserta didik ini dihimbau untuk mengikuti pembelajaran dari rumah melalui siaran di televisi. Dalam transfromasi televisi sebagai media pembelajaran di masa pandemi ini memunculkan berbagai perspektif tersendiri terutama oleh peserta didik itu sendiri.

Pada penelitian yang dilakukan oleh (Wari \& Maula, 2020) pemanfaatan televisi sebagai media pembelajaran di masa pandemi meskipun pada proses pembelajaranya tidak sekondusif ketika di kelas, namun peserta didik merasa senang karena mereka masih menerima materi belajar. Pada penerapan televisi sebagai media belajar memiliki beberapa kendala, salah satunya adalah tidak tersedianya saluran TVRI di beberapa televisi peserta didik. Kendala lainya adalah interaksi antara peserta didik dan pemateri yang tidak langsung sehingga sesi tanya jawab ini tidak tersedia. 
Penelitian lain juga dilakukan oleh (Sudarsana et al., 2020) mengenai pemanfaatan televisi sebagai media belajar selama pandemi. Transformasi televisi sebagai sarana pendidikan ini bertujuan untuk mencapai tujuan pendidikan, yaitu mencerdaskan kehidupan bangsa serta memenuhi hak memperoleh pendidikan. Pada televisi edukasi ini penyajian kontenya harus sangat diperhatikan mengingat tujuanya yang sebagai media edukasi bagi peserta didik.

Penelitian terdahulu juga dilakukan oleh (Atsani, 2020) mengenai transformasi media belajar selama program belajar di rumah memanfaatkan media elektronik salah satunya televisi. Program belajar melalui televisi ini dilaksanakan oleh Kemendikbud berkerja sama dengan saluran televisi TVRI. Hal ini dilakukan sebagai upaya menjangkau peserta didik yang terkendala untuk mengakses internet baik secara ekonomi maupun letak geografis.

Berdasarkan hasil dan pemeparan dari penelitian terdahulu pada kali ini akan dilaksanakan penelitian serupa mengenai transformasi televisi sebagai media belajar dengan lebih menekankan pada perspetif dari peserta didik SMAN 1 Trenggalek. Pada penelitian ini topik penelitian akan dikaji secara lebih lanjut secara sosiologi dengan menggunakan teori tindakan rasional instrumental Max Weber. Perbedaan lain dengan penelitian terdahulu adalah lokasi dan subjek penelitian yaitu peserta didik SMAN 1 di Kabupaten Trenggalek Jawa Timur

\section{Metode}

\subsection{Jenis dan Pendekatan Penelitian}

Pada penelitian ini metode yang akan digunakan yaitu kulitatif dengan pendekatan deskriptif dalam penyajian datanya. (Moleong, 2013) menyebutkan bahwa penelitian kualitatif adalah sebuah jenis penelitian dengan hasil berupa kata-kata atau kalimat berdasarkan sebuah fenomena serta perilaku yang dikaji secara holistik melalui konteks khusus serta metode yang alamiah. Adapun cakupan fenomena serta perilaku yang dimaskud berupa tindakan, persepsi, motivasi, dan segala hal yang terdapat dalam suatu masyarakat. Penelitian kualitatif dengan menggunakan pendekatan deskriptif ini bertujuan untuk menggambarkan secara deskripsi mengenai topik penelitian yang dilakukan.

Metode kualitatif ini dipilih karena dinilai sejalan dengan tujuan penelitian yaitu untuk mengetaui secara lebih dalam dan menyeluruh terkait perspesi peserta didik terhadap transformasi televisi sebagai media pembelajaran di masa pandemi. Melaui penelitian kualitatif ini peneliti mampu memperoleh data secara detail dan mendalam di lapangan terkait studi kasus yang dilakukan.

\subsection{Lokasi Penelitian}

Penelitian ini berlokasi di sekolah menengah atas yang terdapat di Kabupaten Trenggalek Jawa Timur, yaitu SMAN 1 Trenggalek. SMAN 1 Trenggalek ini merupakan salah satu dari 11 sekolah menengah atas negeri yang terdapat di Kabupaten Trenggalek. Pada beberpa waktu yang lalu diketahui SMAN 1 Trenggalek ini mengikuti himbaun pemerintah mengenai pelaksanaan belajar di rumah dengan memanfaatkan media televisi. berdasarkan hal tersebutlah peneliti memilih SMAN 1 Trenggalek sebagai lokasi penelitian. 


\subsection{Teknik Pengumpulan data}

Dalam penelitian ini peneliti memerlukan dua jenis data yaitu data primer dan data sekuder. Data sekunder diperoleh melalui kajian berbagai macam sumber seperti judul, jurnal, hasil penelitian terdahulu, dan berita. Sumber data primer ini digunakan untuk memperkuat data primer secara relevan. Sedangkan data primer ini diperoleh peneliti dengan menggunakan teknik wawancara kepada informan terpilih, observasi dan dokumentasi kegiatan penelitian.

\subsubsection{Observasi}

Observasi pada penelitian ini digunakan untuk mencari dan menentukan calon informan yang akan diteliti. Hal ini dilakukan dengan cara mengamati secara langsung lokasi penelitian. Menurut (Sugiyono, 2014) observasi merupakan sebuah dasar dari ilmu pengetahuan dan observasi ini digunakan untuk mengetahui berbagai fakta yang ada dilapangan. Jenis observasi yang akan digunakan dalam penelitian ini yaitu observasi non parstisipan. Observasi non partisipan merupakan jenis obeservasi dimana peneliti tidak ikut terlibat secara langsung dengan kegiatan informan (Hasanah, 2017). Pada observasi ini peneliti berperan sebagai pengamat lingkungan dari informan. Sehingga pada observasi ini peneliti hanya akan mengamati lokasi penelitian serta mencari calon informan yang dianggap relevan dengan topik penelitian.

\subsubsection{Wawancara}

Pada tahap wawancara ini akan dilakukan secara langsung kepada informan yang terpilih melalui purpose sampling. Adapun tujuan dari teknik purposive sampling yang digunakan untuk menentukan informan yang dinilai relevan dengan topik penelitian melalui pertimbangan tertentu. Wawancara ini akan dilakukan kepada peserta didik dan juga guru guna memperoleh informasi secara rinci mengenai perspektif peserta didik terhadap transformasi televisi sebagai media belajar di tengah pandemi.

\subsubsection{Dokumentasi}

Dalam penelitian ini dokumentasi yang akan dipergunakan berupa foto atau gambar guna memperkuat argumen penelitian agar hasil penelitian dapat dipercaya. Dokumentasi ini bertujuan untuk mengumpulkan berbagai catatan yang telah berlalu. Menurut Sugiyono (2014) dokumentasi ini dapat berupa gambar, tulisan, ataupun karya monumental dari seseorang.

\subsubsection{Teknik Analisis Data}

Data yang diperoleh melalui penelitian kualitatif berasal dari berbagai sumber yang akan dilakukan secara berulang sampai data yang diperoleh telah jenuh. Sehingga analisis ini bertujuan untuk memperkuat dan mendukung kesimpulan serta teori yang digunakan. Analisis sendiri merupakan sebuah proses kritis dalam penelitian. (Moleong, 2013) menyatakan bahwa analisis data dilakukan dengan cara mengurutkan data yang diperoleh sesuai dengan ketegori, pola, serta satuan uaraian dasar sehingga dapat ditentukan topik dan diperoleh kesimpulan sesuai dengan teori yang digunakan dan data yang tersedia. Adapuan alur dari teknik analisis data yang digunakan sebagai berikut : 


\section{a. Pengumpulan data}

Tahap ini dilakukan pada saat sebelum, sesaat dan diakhir penelitian ini berlangsung. Tahap sebelum melakukan penelitian dilakukan dengan menenutukan tema yang akan menjadi fokus penelitian. Sedangkan pada saat penelitian pengumpulan data dilakukan secara terus menerus hingga data yang diperoleh jenuh dan penelitian berakhir.

\section{b. Reduksi data}

Pada tahap ini seluruh data yang terkumpul diseleksi guna mendapat data yang benarbenar sesuai dengan topik penelitian. Reduksi ini bertujuan mengumpulkan data pokok yang dinilai penting dari hasil yang diperoleh salam turun ke lapangan yang bertujuan memberikan gambaran yang jelas agar memudahkan peneliti untuk melengkapi kekurangn data yang diperoleh untuk penelitian.

c. Penyajian data

Penyajian data pada penelitian kualitatif berupa sekumpulan informasi yang dapat memberikan gambaran dari penelitian yang dilakukan. Data yang peroleh selama penelitian disajikan secara tersusun dan terperinci serta holistik guna mencari pola hubungan data yang diperoleh. Sehingga pada tahapan ini penarikan kesimpulan dapat dilakukan.

\section{d. Penarikan kesimpulan}

Pada tahapan ini semua hasil penelitian ditarik kesimpulan dan dilakukan evaluasi yang bertujuan mencari makna, arti serta penjelasan secara singkat mengenai data yang telah dianalisis dengan melibatkan hal-hal pokok yang penting. Kesimpulan ini diambil sesuai dengan data yang diperoleh dilapangan tyang sesuai dengan tema dan fokus penelitian.

\section{Hasil dan Pembahasan}

Berdasarkan penelitian yang dilakukan pada peserta didik SMAN 1 Trenggalek melalui wawancara di peroleh hasil adanya bentuk-bentuk transformasi televisi sebagai alternatif media belajar yang digunakan oleh guru. Penggunaan televisi sebagai media belajar ini juga di dukung oleh program pemerintah secara terstruktur pada beberapa mata pelajaran inti. Guru juga menjadikan televisi sebagai media belajar yang dikembangkan guna menyesuaikan dengan kondisi masa pandemi Covid-19. Disisi lain transformasi ini memberikan berbagai perspektif dari peserta didik pada saat pembelajaran jarak jauh berlangsung.

\subsection{Bentuk Transformasi Televisi Sebagai Media Belajar di Masa Pandemi}

Pada masa pandemi ini media pembelajaran telah mengalami berbagai macam penyesuaian, salah satunya dengan menggunakan media televisi. Kemudahan penggunakaan dan ketersediaan televisi menjadi alasan untuk menjadikannya sebagai alternatif media pembelajaran bagi siswa dan guru dalam menjalani pembelajaran jarak jauh di masa pandemi Covid-19. Televisi telah mengalami transformasi menjadi media pembelajaran. Transformasi televisi ini berupa fungsi dari televisi bukan haya sebagai media hiburan dan informasi saja. Saat ini media televisi telah menjadi media pendidikan yang di rekomendasikan oleh pemerintah dan sekolah. Sebelumnya beberapa program televisi sudah terdapat tayangan edukasi seperti Laptop Si Unyil, Si Bolang dan lainnya namun hanya sebagai tanyangan edukasi di rumah dan tidak disertai bimbingan oleh guru. Maka terdapat transformasi fungsi televisi sebagai media pembelajaran formal di sekolah. 
Pembelajaran menggunakan media televisi saat ini mendapat dukungan dari pemerintah, sekolah dan guru. Sehingga penggunaan media belajar televisi lebih terstruktur. Bahkan pemerintah menyediakan televisi pendidikan yaitu TVRI sebagai salah satu tayangan pembelajaran untuk peserta didik. Pada proses pembelajaran yang disediakan pemerintah ini memiliki jadwal yang terstuktur seperti pada jenjang sekolah menengah pembelajranya berlansung pada hari dan jam yang berbeda dengan jenjang pendidikan dibawahnya. Kegiatan belajar melelui televisi melalui siaran TVRI ini peserta didik diminta untuk mengamati materi yang diberikan kemudian mengerjakan tugas sesuai apa yang disampaikan. Tugas tugas ini nantinya diserahkan kepada guru mata pelajaran yang bersangkutan untuk dilakukan evaluasi. Dalam transformasi televisi ini peran guru juga masih diperlukan sebagai pengontrol dan pembimbing peserta didik saat kegiatan belajar berlangsung.

Pembelajaaran melalui televisi ini hanya diterapkan pada beberapa materi inti saja seperti matematika, IPA, IPS dan bahasa dan berlangsung selama 3 sampai 4 kali pertemuan. Disisi lain pembelajaran juga tidak memiliki batasan hanya menggunakan tayangan yang disediakan, namun guru dapat berinovasi dengan menggunakan tayangan lainnya seperti acara berita. Setelah peserta didik menonton tayangan pembelajaran, guru memberikan sesi diskusi atau membuka sesi pertanyaan terkatit pembelajaran yang telah dilakukan.

\subsection{Perspektif peserta didik terhadap transformasi televisi sebagai media belajar di masa pandemi}

Dalam menyikapi suatu fenomena baru selalu diiringi dengan berbagai perspektif dari individu yang terlibat. Seperti pada penggunaan televisi sebagai media pembelajaran di masa pandemi. Televisi mengalami transformasi sebagai media belajar pad pembelajaran jarak jauh memberikan respon yang cenderung tidak baik oleh peserta didik. Mayoritas peserta didik ini menilai pembelajaran melalui media televisi ini kurang efektif dimana komunikasi yang terbentuk hanya satu arah. Pada dasarnya proses pembelajaran memerlukan komunikasi dari segala arah dengan tujuan peserta didik ini tidak hanya menerima namun juga memahami konsep-konsep yang dipelajari.

Pada proses pembelajaran dengan memanfaatkan media belajar televisi ini memang mampu menambah wawasan ilmu pengetahuan peserta didik. Dimana pada proses belajaranya mereka bisa menerima pengetahuan dari sumber yang lebih luas, misal adanya tugas menganalisi suatu berita di televisi tentang kondisi saat itu. Hal ini tentunya merupakan hal baru yang mampu menambah pengalaman belajar peserta didik. Namun juga memberikan kesulitan pada peserta didik dimana mereka tidak bisa bertanya mengenai konsep yang dijelaskan dan materi yang diterima tidak bisa diulang. Ketika peserta didik ini tidak paham dengan materi yang diperoleh melalui televisi mereka bisa berdiskusi dengn guru mata pelajaran yang bersangkutan, namun lagi-lagi tidak semua guru membuka ruang diskusi bagi peserta didik. Dalam hal ini proses belajar yang terjadi adalah peserta didik hanya menerima apa yang disampaikan.

Para peserta didik juga menilai bahwa kegiatan belajar melalui televisi ini kurang nyaman dan tidak efiesien untuk dilakukan karena mereka harus bersiaga didepan televisi. Sedangkan disisi lain mereka memiliki tugas lain. Selain itu tidak tersedianya saluran televisi yang ditentukan oleh pihak sekolah juga menjadikan hambatan tersendiri bagi peserta didik untuk mengikuti kegiatan pembelajaran. 


\subsection{Transformasi Televisi Sebagai Media Belajar di Masa Pandemi sebagai wujud rasionalisme instrumental}

Saat ini televisi tidak hanya sebagai media untuk hiburan dan mendapatkan informasi terkini, namun televisi secara perlahan perlahan bertranformasi unrtuk menjadi media yang lain yaitu dalam hal pendidikan atau belajar. Tidak bisa dipungkiri bahwa kemajuan teknologi menyebabkan perubahan perubahan baru kepada teknologi yang bahkan bisa saja menggeser sepenuhnya teknologi lama dengan teknologi yang baru. Apalagi saat ini, orang diseluruh dunia sedang mengalami pandemi COVID-19. Sehingga mau tidak mau semua aktivitas mulai aktivitas sehari hari, pekerjaan hingga pendidikan harus dilaksanakan secara online. Salah satu teknologi yang bertransfotmasi demi memenuhi kebutuhan di tengah pandemi ini adalah televisi. Sekarang di televisi menjadi salah satu media untuk pemberian ilmu pengetahuan dan sumber belajar bagi peserta didik. Dimana dalam televisi tersebut ada interaksi kegiatan belajar dan mengajar. Saat ini, televisi bisa menjadi salah satu media belajar yang dapat dijangkau oleh seluruh daerah di Indonesia. Karena biasanya masyarakat di daerah pelosok dan pedalaman pasti memiliki televisi daripada akses internet.

Fenonema bentrasformasinya televisi dari media hiburan dan pemberian informasi menuju media yang digunakan menjadi belajar saat pandemi ini bisa dikaitkan dianalisisi dengan rasionalisme instrumental milik Max Weber. Secara singkat, rasionalisme instrumental ini adalah suatu tindakan yang dilakukan atas dasar pertimbangan serta pilihan sadar untuk mencapai tujuan dengan menggunkan alat untuk mencapai tujuan tersebut. Dimana hal ini sesuai dengan fenomena ini, Karena proses transformasi televisi ini dari media hiburan bukan tanpa sebab. Proses transformasi ini dikarena untuk memenuhi kebutuhan peserta didik untuk belajar dan melakukan kegiatan pembelajaran selama pandemi ini yang harus menyebabkan segala aktivitas harus dilakukan dirumah sebagiai pencegahan menyebarkan COVID yang semakin luas. Pertimbangan kenapa televisi digunakan sebagai media belajar untuk memenuhi kebutuhan peserta didik adalah televisi merupakan teknologi yang menjangkau seluruh lapisan masyarakat dan semua wilayah. Karena hampir semua orang memiliki televisi mulai dari masyarakat kebawah dan terpencil hingga masyarkat kelas atas dan perkotan. Sehingga bisa disimpulkan bahwa rasionalisasi instrumental dari adanya fenomena bertransformasi televisi media belajar adalah untuk memenuhi kebutuhan peserta didik dalam hal pendidikan di tengah pandemi COVID ini dan juga salah satu teknologi yang dapat diakses bagi seluruh lapisan dan juga wilayah serta tidak perlu mengelurkan biaya lain selain listrik. Sehingga hal ini lebih mudah digunakan dan murah daripada gawai yang harus menggunakan akses internet untuk mendapatkan materi belajar. 


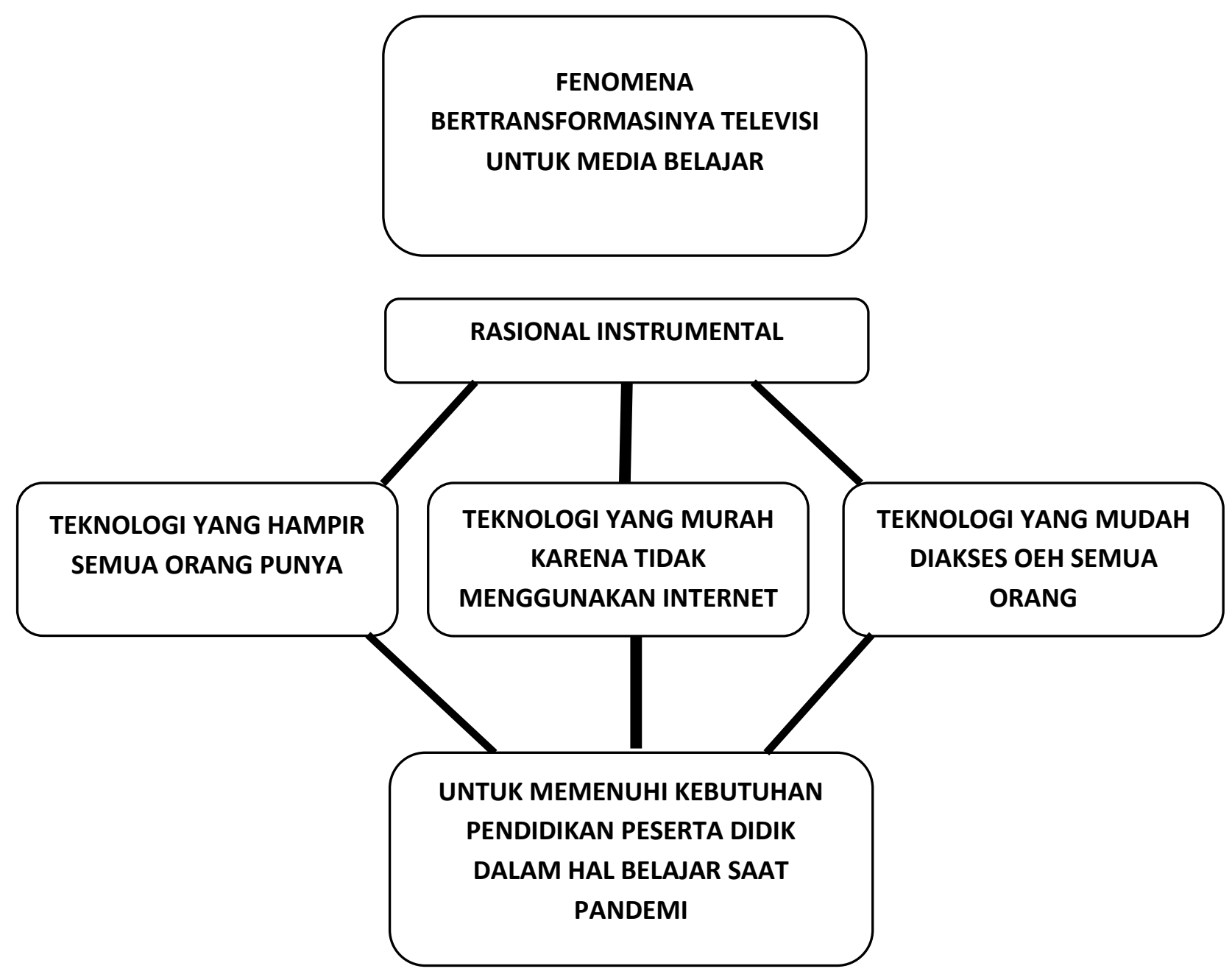

Gambar 1. Bagan Hasil Penelitian

\section{Simpulan}

Dengan adanya pandemi COVID ini, banyak teknologi yang bertransformasi untuk memenuhi segala kebutuhan masyarakat yang tidak bisa dilaksanakan dan terpenuhi. Karena masyarakat di himbau untuk tetap dirumah guna mencegah dan terpapar COVID ini. Sehingga segala akitvitas yang membutuhkan kontak langsung dan orang banyak harus ditiadakan. Hal ini menyebabkan penyesuaian baru dalam masyarakat dan mau tidak mau harus memanfaat teknologi yang ada. Kasus dari adanya hal ini adalah dalam dunia pendidikan, yang awalnya peserta didik datang ke Lembaga pendidikan seperti sekolah untuk berinteraksi langsung untuk mendapatkan materi pembelajaran harus ditiadakan dan diganti secara daring. Sehingga menyebabkan banyak teknologi bertranformasi untuk memenuhi kebutuhan peseta didik di tengah pandemi ini yaitu adalah televisi. Televisi yang awalnya merupakan media hiburan sekarang perlahan menjadi media belajar juga di tengah pandemi ini. Jika dilihat dari sudut pandang tindakan rasionalisme instrumental, pertimbangan kenapa teknologi televisi ini bisa bertransformasi sebagai media belajar itu karena televisi merupakan teknologi yang hampir dipunyai oleh seluruh lapisan dan wilayah di masyarakat serta penggunaannya yang mudah dan murah tanpa mengeluarkan uang untuk membayar akses internet.

\section{Daftar Rujukan}

Atsani, K. H. L. G. M. Z. (2020). Transformasi media pembelajaran pada masa Pandemi COVID-19. Al-Hikmah: Jurnal Studi Islam, 1(1), 82-93. 
Jurnal Integrasi dan Harmoni Inovatif Ilmu-Ilmu Sosial (JIHI3S), 1(2), 2021, 116-124

Hasanah, H. (2017). Teknik-teknik observasi (sebuah alternatif metode pengumpulan data kualitatif ilmu-ilmu sosial). At-Taqaddum, 8(1), 21-46.

Moleong, L. J. (2013). Metode penelitian kualitatif (Revisi). Bandung: PT. Remaja Rosdakarya.

Sudarsana, I. K., Lestari, N. G. A. M. Y., Wijaya, I. K. W. B., Krisdayanthi, A., Andayani, K. Y., Trisnadewi, K., Muliani, N. M., Dewi, N. P. S., Suparya, I. K., \& Gunawan, I. G. D. (2020). Covid-19: Perspektif Pendidikan. Yayasan Kita Menulis.

Sugiyono, P. (2014). Metode Kuantitatif Kualitatif dan R \& D. Jakarta: Alfabeta.

Wari, R., \& Maula, L. H. (2020). Analisis Pendapat Siswa Tentang Pembelajaran Berbasis Media Televisi Selama Pandemi Covid-19. Jurnal Perseda: Jurnal Pendidikan Guru Sekolah Dasar, 3(2), 99-104. 